\title{
DECLARACIÓN DEL MOVIMIENTO DE UNIFICACIÓN ARAUCANA
}

Santiago, Junio 24 de 1960

Señor

Dr. Alejandro Lipschutz

Presente

De nuestra atenta consideración:

El movimiento de unificación araucano, en su sesión del 23 del presente, acordó enviar esta acta para su conocimiento y consulta a los distintos hombres de ciencia, acerca de un hecho cometido por la machi de Puerto Saavedra, en el lugar denominado Loncopulli.

Según informes proporcionados por el Juzgado de Nueva Imperial y los diarios, este suceso habría acontecido el 10 del presente en el sitio ya mencionado. Un grupo de indígenas muy atrasados practicaron un ritual a semejanza de los que se efectuaban en épocas milenarias en diversas culturas de gran desarrollo pertenecientes al periodo precolombino, y que su tradición oral sobre el diluvio fue llevada a distintos lugares del Continente, en sus múltiples migraciones.

Ahora, según versión propalada, unos mapuches cercanos al lago Budi, de estado cultural muy primitivo, reactualizaron la tradición en una ceremonia de guillatún, inmolando un niño a orillas del mar, ofreciéndolo como holocausto a sus dioses. Una vez sacrificado el niño sus restos fueron lanzados al mar para así aplacar la ira y terminar con el terremoto.

Los hechos fueron practicados por la machi María Luisa Namuncura: la víctima ceremonial, el menor José Quinen Paiñen, ayudantes de la machi, Juan Paiñao, todos aborígenes se encuentran detenidos esperando el dictamen de la justicia.

Ante esta situación, y después de relatar brevemente el hecho el movimiento de Unificación Araucano, se ha pronunciado en forma categórica, en los siguientes términos: 
I.- Nos conmueve profundamente el hecho cometido por los mapuches de Puerto Saavedra;

II.- Que el sacrificio ceremonial ofende las normas de la actual civilización Occidental;

III.- Que la cultura de esos aborígenes selváticos está sumamente atrasada, con profunda carencia de orientación cultural y huérfanos de toda ayuda que le permitan grados de evolución a fin de incorporarse a las normas de conducta social que rigen a nuestro país;

IV.- Que el suceso fue ocasional, basado en las tradiciones diluvianas de épocas antiquísimas;

V.- Que este suceso doloroso ha sido aprovechado por algunos diarios y otros medios de información con fines comerciales o son sensacionalistas, que con sus acusaciones pretenden conseguir, a la postre, para los interesados sus ansias de desprestigio del mapuche;

VI.- Que conocemos la historia de otros pueblos antiguos; romanos, griegos, persas, egipcios, etc. que en época de barbarie cometieron también estos mismos hechos sacrificando seres humanos como ofrendas a sus dioses, y que estos mismo pueblos, son su evolución, son ahora portadores de mejores formas de vida civilizada y base de la cultura moderna;

VII.- Deseamos una interpretación a juicio de los hombres de ciencia, conocedores de la historia, de la sociología, de la antropología, de la etnología, etc. Cuyas disciplinas estudian en una $u$ otra forma al ser humano, sus costumbres y evolución. Queremos que estos hombres de ciencias, sean peritos en esta materia tan delicada.

VIII. Declaramos que no se puede juzgar este hecho ceremonial sin conocer la cultura del pueblo mapuche, y tampoco estimamos que el suceso pueda ser motivo de un veredicto desde el puto de vista puramente jurídico proveniente de otra cultura que le ha negado a la raza araucana los legítimos medios para su incorporación integral a la nacionalidad.

Por lo tanto, y en mérito de lo que exponemos, venimos en solicitar de Ud. integre la comisión de ciencia para que públicamente entregue un estudio acerca de este delicado problema que exponemos.

Saludan muy atentamente a Ud. 


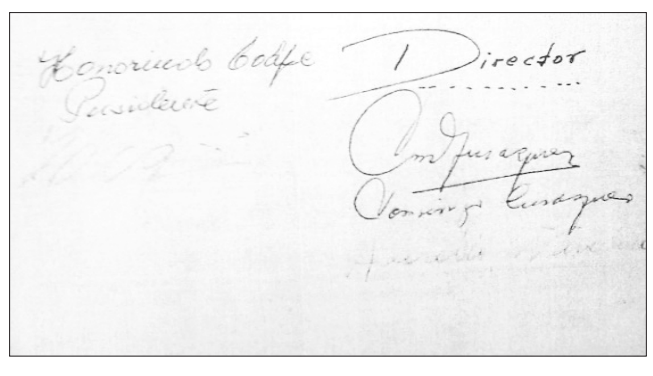

Honorindo Colipe

Presidente

Domingo Curaqueo

Director

Aurelio Nancucheo

Secretario 